\title{
Care and Counterinsurgency
}

Daniel H. Levine

August 2009

MAR UNIVRSITY OF

\section{CISSM}

School of Public Policy

4113 Van Munching Hall

University of Maryland

College Park, MD 20742

Tel: (301) 405-7601

cissm@umd.edu
The author would like to thank the Smith-Richardson Foundation for its generous support during the research and writing of this paper. 
Running Title: Care and Counterinsurgency

Daniel H. Levine

Assistant Professor, School of Public Policy

Assistant Research Scholar, Institute for Philosophy and Public Policy

University of Maryland, College Park

3111E Van Munching Hall

University of Maryland

College Park, MD 20742

Correspondence and corrections can be directed to Dr. Levine

Bio: Dr. Levine joined the faculty of the Maryland School of Public Policy from the US Institute of Peace, where he served as a Program Officer in the Education and Training Center. His current research interests include peacekeeping, asymmetric warfare, security issues in Africa, and international law on the use of force. Dr. Levine holds a Ph.D. in Philosophy from Georgetown University and a Master of Public Policy from the University of Maryland.

Abstract: Counterinsurgency demands different tactics than conventional warfare, and as a result requires a different moral perspective as well. Counterinsurgents face a situation in which the distinction between civilians and combatants can be obscure, and where they are expected not just to defeat an enemy but to actively promote the interests of, and build trust with, the civilian population. What counterinsurgents need is not new moral rules of war so much as new virtues that will let them conduct their activities, within the moral minimums set by the rules of war, in a way more coherent with the implicit values of just counterinsurgency. These virtues have been explored in what may be a surprising area - discussions of the 'ethic of care' inspired by the need to manage urges to violence and anger in the context of building trust relationships in the family. Reflection on the ethics of care can reveal a way of thinking about counterinsurgency that highlights the importance of developing attentiveness, creativity, and restraint in a counterinsurgent's relations both with civilians in the area of operation and even with insurgent combatants.

Keywords: Counterinsurgency, asymmetric warfare, ethics of care, virtue, civilian/combatant distinction

Acknowledgments: The author would like to thank Alix Boucher, Lauren Fleming, Nancy Gallagher, Joe Oppenheimer, Melissa Schober, Jeremy Snyder, Robert Wachbroit, Alec Walen, J.D. Wooten, and the participants in the Institute for Philosophy and Public Policy's "Ideas Under Construction” series and the Center for International and Security Studies at Maryland's lunch forum series for their comments on this paper. The author would also like to thank the SmithRichardson Foundation for its generous support during the research and writing of this paper 


\section{Care and Counterinsurgency}

\section{Introduction}

Counterinsurgents have a different relationship with both their enemies and civilians in the area of operations than conventional warfighters. For counterinsurgents, civilians are not just bystanders who need to be kept out of the way of the fighting - they are actively enlisted, coerced, and fought over by both sides. And, enemy combatants are not just targets of kinetic operations, they are potential sources of information, potential allies, and often members of the very community that the counterinsurgency is supposed to be aiding.

In this paper, I will argue that these observations have two serious implications for the training of counterinsurgents. First, the moral challenges of counterinsurgency should be met not with more-finely-crafted rules but with virtues of character. Counterinsurgents are placed in complex situations in which even low-ranking personnel will need to exercise their judgment in ways that rules are unlikely to fully capture.

Second, the virtues that counterinsurgents should exhibit are importantly different from the core of the 'warrior ethos' that most Western militaries inculcate. ${ }^{1}$ Counterinsurgency requires military virtues, such as loyalty and devotion to service, of course. But it also requires distinctive virtues of attentiveness, creativity, and restraint - as well as a subtly but importantly modified concept of courage.

The distinctiveness of counterinsurgency can be captured in part by the idea that counterinsurgents are not primarily out to defeat an enemy, but rather to rebuild a relationship of trust between a government (of which counterinsurgents may or may not be a part) and its citizenry. An insurgency is an armed conflict internal to a nation-state, where the goal is a significant change in the form of government. ${ }^{2}$ Insurgents are typically, but not universally, much weaker militarily than their government opponents, and hence often resort to irregular warfare tactics. But these functional definitions can obscure a key element. Counterinsurgency is not just a traditional war that happens to be waged in areas with large civilian populations, between forces of mismatched military power. Rather, it is a battle over which side will be perceived as legitimate in the eyes of the population (Headquarters Dept. of the Army, 2006: $\S \S 1-3,1-4)$.

Killing or capturing insurgents is not the main game for counterinsurgents, and may even be counterproductive. The effort to 'win hearts and minds' among the population means that force

1 My sense is that this ethos is more widespread than just among Western militaries - especially because of the work that Western militaries do in terms of outreach and training of other personnel.

2 I will not attempt to define "legitimacy" in any great detail here, and will settle for the rough intuitive definition that it is a widespread belief that an authority ought to be obeyed (in most cases). 
must be used to provide civilians security from threats to them (not just to protect counterinsurgents from military threats). The need to use force to establish credibility and control creates a tension for counterinsurgents. Coercive and forceful measures often involve violence or the threat of violence, and so risk harming the very people whom counterinsurgency must benefit to be successful and worthwhile. If people are inclined to see the counterinsurgents as illegitimate, when they use force it may cause people to believe that counterinsurgents should be resisted by force, leading to greater insurgent recruitment.

Discussing how to navigate that tension will be the topic of this paper, and I hope it will redeem my claims about character virtues, above. In the course of the discussion I will also make good on the title of this paper. I believe that the resources for thinking about some of the issues specific to counterinsurgency are to be found in the tradition of 'care ethics' - a branch of ethics that has its roots in feminist thought (but has applications beyond its original context) and deals head-on with questions of how to build relationships in the presence of coercion, power imbalance, force, and even violence.

One caveat/assumption: I will assume that at least some counterinsurgency campaigns are just, and that we are talking about considerations that apply to just counterinsurgents. ${ }^{3}$ My discussion will focus on how to conduct otherwise just counterinsurgency in a moral manner, though I will have a bit to say about how the issues raised here might impact the overall justice of the war at the end. ${ }^{4}$

\section{'Winning Hearts and Minds'}

The fact that counterinsurgency is a battle for legitimacy does not mean that counterinsurgents should be social workers, humanitarians, or propagandists.

The British counterinsurgency in Malaya, which gave us the phrase, is the classic example of how 'hearts and minds' tactics are combined with more coercive approaches in effective counterinsurgency. The British created 'new villages' to which Malays in insurgent-dominated areas were coercively relocated. In these villages, the British could better exercise control, and they ultimately focused on providing improved services to the villages, that would make life there (after the 'initial disturbance of moving') more attractive than under insurgent control (Stubbs 2008: 122-4).

Merely rounding up the population into the villages did not work well - it was only after the

3 I'd rather not take a stance on the independence of the justice of a war and the justice of conduct in that war here, an assumption of traditional just war theory which has come under serious assault recently (e.g., in McMahan (2009)). By assuming that we are talking about just counterinsurgents, though, I believe my arguments will apply regardless. Unjust combatants may not be able to pursue war justly, but just combatants must also attend to additional constraints on conduct.

4 In the jargon of traditional just war theory, my topic here is jus in bello, the just conduct of war, rather than jus ad bellum, the justice of resort to war. 
British started providing safety and the benefits of governance to villages, and began offering independence (one of the insurgents' main stated goals) that they began to turn the war around.

Secondly, this was not just a matter of persuasion - had the British not created the new villages, where they could exercise increased control, anything they tried to build would have been targeted by insurgents. And, it is unlikely that people would have moved into the new villages without coercion. Whatever its virtues, the British strategy was not bloodless or 'nice.' And so anyone seeking to emulate it faces serious moral questions about whether or not they are doing wrong by the population by subjecting them to a counterinsurgency in the first place and about how to treat a population that they plan to subject to coercive and even violent measures, so that trust in the government is ultimately built rather than undermined.

It may be tempting to take the coercive elements of counterinsurgency as reason to condemn counterinsurgency entirely. After all, one of the core principles of traditional just war thought is force is not to be used, intentionally, against non-combatants. Even though the aim of counterinsurgency is not to kill non-combatants, they are coerced with military force as an element of strategy. Even if forced resettlement is a fairly rare and extreme tactic, other coercive measures aimed at population control are part of mainstream counterinsurgency strategy, such as significantly limiting the freedom of movement of civilians in areas the counterinsurgents are focusing on or conducting repeated and intrusive searches (Headquarters, Department of the Army 2006: esp. §5-73). These restrictions are backed up with the threat of force. There would be something disingenuous about, e.g., a counterinsurgent force declaring a curfew, using force to detain (or even kill) anyone violating that curfew, and then insisting that there was not even a moral question about the use of force against civilians since, after all, only curfew violators were targeted.

Does this mean that counterinsurgency is morally incoherent, or that it violates fundamental principles of non-combatant immunity? I do not think so, but its moral contours are likely to be different from those of conventional warfare. Since counterinsurgents are trying to win over the civilian population, and build a stable relationship of trust in the government's ability and authority to provide for human security, The relevant questions to ask about the counterinsurgent's moral situation is: how can one build a positive relationship in a context of force, violence and coercion, especially when coupled with asymmetric power? What kind of person could use force responsibly when he or she faces a vulnerable person with whom building trust is necessary?

Some answers can be found in what may seem to be an unlikely place: in the strand of feminist ethics known as the ethic of care. 


\section{Violence and the Ethic of Care}

There are many variations on care ethics, and so not everything I say would be endorsed by every care ethicist. But I will try to outline the major issues, while picking and choosing elements from several thinkers - my goal in this essay is not to break any ground in the theory itself, but rather show the contribution the approach can make to thinking about counterinsurgency and other non-traditional warfare.

As Daniel Engster puts it, care ethics is focused on 'meeting the basic needs of individuals, developing their capabilities, and helping them to survive and function' (2007: 26). While benevolence is a feature of most every moral theory, it is given a central place in care ethics, in contrast to most other moral approaches, e.g., Kantianism.

To a focus on promoting well-being, care ethics typically adds a focus on particularistic attachments. For Virginia Held, the 'central focus of the ethics of care is on the compelling moral salience of attending to and meeting the needs of the particular others for whom we take responsibility' (2006: 10). Care ethics does not ignore our more universal moral obligations. But care ethicists attempt to build universal obligations out of extensions of particular attachments, rather than deriving the value of particular relationships from universal moral rules.

Care ethics also identifies a characteristic basis of obligation. Where, e.g., utilitarian ethics bases moral obligation on the value of happiness, and Kantian ethics on the necessity of respecting rational dignity (and so forth), care ethicists base the obligation to care for others on the fact that we all are dependent on the caring relationships others have with us. Most obviously, we are all radically dependent on care in our infancy, and often in our old age. More subtly, we depend on the cooperation of others in myriad moments of sickness, weakness and error, and more generally to maintain the social structures and context that allow us to live our lives as they are. The fact of dependence is central to most care ethicists' accounts of obligation, even though they may differ on whether dependence is important because of the inherent moral force of the needs of the vulnerable (Held 2006: 10), the perversity involved in denying to others what we will demand ourselves (Engster 2007: 40), or because an empathic connection to others that motivates one to aid them when they are vulnerable is part of being a fully morally developed human being (Slote 2007: 16).

Care ethics is connected to violence in two ways. First, those who use or are prepared to use violence are sources of vulnerability for others, whether by intent or accident.

Second care ethics' particularism and focus on relationships pushes non-rational elements of our moral situation to the fore. I may have perfectly good reasons for coercing you to do something - it may be absolutely just, and anyway for your own good. But if I care about you, I also need to recognize and account for the way in which you may not simply take my coercion in stride, as justified. In addition, I need to keep vividly in mind my own prejudices and errors, and may go 
wrong if I decide that I know what is best without listening to what you think is best.

Conversely, if I care about you, I also cannot simply take refuge in the idea that you are an autonomous human being and the use of coercion against you is always wrong - there are times when we must rely on others to protect us 'against our will,' when we are weak-willed, unable to cooperate with others, vulnerable to manipulation, or overcome with emotions like fear, anger, or even triumphalism. This is not to make an apology for unrestrained paternalism, but rather to insist that coercion is an ever-present possibility of caring, and that the question of when it should be used cannot be answered easily, or in the abstract.

Care ethics may tend to focus on the cultivation of positive emotions and psychological states, such as love, empathy, and concern - and so to have little to say about a military context, where coercion often means the use of force and violence. But, it would do a disservice to the ethic of care to think of it as being entirely about harmony and the 'softer' emotions. Care ethics has an advantage in considering coercion from a perspective that is less abstract, and rooted in the difficulties of people trying to maintain relationships where anger and frustration are prevalent, and where violence can be a tempting and ready option. ${ }^{5}$

From its beginnings in feminist reflections on motherhood, the ethic of care has been intimately concerned with force. Parenting is a situation in which there is a great imbalance in possession of the tools of force, as the records of child abuse and child deaths demonstrate. Furthermore, feminists working in the ethic of care have faced the fact that parenting is a situation in which parents are often sorely tempted not just to coercion but to violence. Anyone who associates parenting solely with love and harmony has a superficial understanding of the phenomenon. Reflection on the ethic of care grounded in the experience of parenthood can thus help us illuminate issues of violence, even though parenthood cannot be used as an analogy to counterinsurgency warfare. ${ }^{6}$

There is at least one point of analogy between parenting and counterinsurgency - as I noted above, counterinsurgents find themselves in a situation where the use of coercion may be necessary, but where they cannot succeed without building a relationship with some of the very people against whom they may feel called to use force. Navigating this tension requires a kind of clear-headed constraint that is most difficult to maintain when, like a counterinsurgent, one is relatively isolated with a recalcitrant or hostile population (recalcitrance may be even more frustrating when it comes from 'ungrateful' people counterinsurgents see themselves as helping), and has at hand overwhelming tools of violence that can be used as a short-term solution.

5 In 2006, the rate of fatalities from child abuse in the US was 2.04 per 100,000 children (http://www.childwelfare.gov/pubs/factsheets/fatality.cfm). The murder rate in the overall population in 2007 was only 5.9 per 100,000 (http://www.fbi.gov/ucr/cius2007/data/table_16.html).

6 Of course, this might be said of other ethical perspectives as well. Kant's ethics in the Grounding for the Metaphysics of Morals ([1785] 1993) focus primarily on social relations like deceit and charity, but this is no objection to a Kantian military ethic. 
My use of the word 'violence' rather than 'force' here is intentional. 'Force' is a relatively bloodless word, and while it is fine for many purposes it, along with other military jargon like 'kinetic operations' can obscure some of non-rational features of counterinsurgency warfare that we should attend to from a moral standpoint. ${ }^{7}$ Force could mean gently but firmly pulling a stubborn child out of the street. Violence is the use of force to injure, maim, or kill. ${ }^{8}$ Counterinsurgents, even when they do not use their military power directly, are constantly and obviously backed by the fact that they use and threaten violence. This is not to condemn counterinsurgency, of course - sometimes violence must be used. But we should recognize that counterinsurgents' use of and potential for violence tends to evoke anger and fear, and care must be taken lest those emotions undermine the counterinsurgency. At the same time, anger, uncertainty, isolation, stress, and the consciousness of physical superiority - common conditions of counterinsurgency - tend to urge human beings to violence. Sara Ruddick describes the situation for (for the case of parents) nicely:

... what is striking about mothers is their commitment to nonviolent action in precisely those situations where they are undeniably powerful... Children are vulnerable creatures and as such elicit either aggression or care. Recalcitrance and anger tend to provoke aggression, and children can be angrily recalcitrant. Typically the mother who confronts her children is herself young, hassled if not harassed by officials in an outside world, usually by her own employers, and often by the adults she lives with. She brings to confrontation with her children psychological and physical strengths which are potentially lethal. Her ability to damage her children increases the more she is alone with them, the less others are available to go to the children's aid. Yet it is these same circumstances of frustration and loneliness that will tempt her to violence when faced with her children's recalcitrance. (Ruddick [1989] 1995: 166)

Nonetheless, Ruddick points out, most mothers/parents refrain from violence. To do so, parents develop virtues of character that counteract impulses to violence. Ruddick (rightly) takes pain to avoid any appeal to an inherent connection between femininity and non-violence; that sort of essentialism and mysticism about the feminine is naïve at best. ${ }^{9}$

The experience of nurturing can cut both ways, insofar as it tends to create a deep psychological investment in the unique and fragile value of individuals. Some parents might be inspired by this experience to resist violence at all costs. Others might be inspired, by that same investment in the value of life, to militarism when those they nurture are threatened. 'If her son is killed while

7 For an interesting (if sometimes perhaps overstated) discussion of the way military language can channel the kinds of moral concerns that are and can be raised, see Cohn (1987).

8 Following Coady, I think we should include some forms of psychological violence, inflicted by force, in the definition. While it is easy to cast the net too wide here, the intent is not to include any and all bad feelings that might arise from coercion. Rather, the point is that is possible to inflict severe psychological trauma without inflicting much physical harm - using a position of superior force to frighten or degrade a target, etc. For instance, it seems appropriate to consider reported uses of dogs to terrorize detainees at Abu Ghraib as instances of violence. See the discussion in Coady ()

9 For a recent (naïve) example of an argument that women are simply inherently more peaceful, see Solomon (2009). 
killing, should his mother deny herself the consolation of giving his 'sacrifice' a point?' (Ruddick [1989] 1995: 155; see also 177) Parenting produces both the pacifist activism of the Women in Black and the chilling statements of some Palestinian mothers that they hope all their children will be martyred in the struggle against Israel.

What feminists like Ruddick find in the practice of parenting is a domain where certain virtues that are 'resources' for non-violence can be developed (Ruddick [1989] 1995: 157).

This is not to say that parents do not use force and coercion. Even parents who do not believe in corporal punishment may face the choice of whether and how to forcibly return a recalcitrant child to 'time out' or similar punishments that require physical control. And force is sometimes appropriate to stop a child from doing something harmful or dangerous when persuasion is infeasible or inappropriate. A child may pose little threat to a parent, but may be able to visit grievous harm on another child unless an adult forcefully intervenes.

Parenting thus requires a careful calibration in the use of force. Effective parents cannot simply determine that they will never use force against children. But the use of force tends to undermine the relationship of trust that one hopes to build with one's children - even when justified, it is likely to create (at least temporary) feelings of fear and/or resentment, and to bring us close to the brink of violence. No parent is a purely rational agent - given the stresses of parenting, it is easy for a limited use of force to get out of hand and endanger a child.

\section{Care and Counterinsurgency}

The resources for non-violent action that parents develop are virtues of character that allow a parent to keep his or her 'cool' when violence is tempting; these virtues are just as relevant for an activist as a parent (as Ruddick argues), or when limited coercion and especially limited violence are the goal, rather than total non-violence. Care ethicists call attention to several virtues that are especially important to the counterinsurgent.

What care ethics can illuminate about counterinsurgency is not new rules of war. Even given what I have said about the necessity of coercive tactics against civilians above, some distinction between civilians and combatants remain - it is not as if understanding counterinsurgency causes us to lose our intuitive grip on the difference between, say, the imposition of curfews and checkpoints by US forces in Iraq and the widespread ethnic cleansing (arguably even rising to genocide), displacement, and violence against civilians used as a counterinsurgency tactic by the government of Sudan in Darfur.

Trying to articulate a new principle of discrimination that specified all and only the kinds of coercion, backed by the implicit threat of violence, that may be morally used against civilians is not the most productive way to approach the problem. Civilians are not passive bystanders to a conflict the way they are conceived to be by the traditional principle of discrimination - whether 
willingly or not, they are involved intimately in the conflict itself, both because their loyalty is the 'prize' in the conflict, and because of the way that insurgency relies on the civilian population.

Insurgents live among the broader population, and depend on them for cover, as well as material and moral support. An insurgent may complete a military action and then return to the home in which he or she lives with his or her family, participate in family life, and then return to the fray in a commercial vehicle using weapons purchased through the same criminal channels that bring in non-military illegal items. While the base in which American soldiers sleep would generally be considered a morally and legally legitimate target, whether or not it would be immoral to attack an insurgent's home is a dicier matter.

This ambiguity is often blamed on the insurgents - the possible immorality of targeting a civilian home has to do with the civilians living there, and it was the insurgent's choice to live among them rather than protecting them by basing outside a civilian area, after all. From the standpoint of minimizing 'collateral damage,' coercively moving civilians out of areas where insurgents can live among them might seem like a morally obligatory lesser evil.

The issue is not that simple. Cooks working for military contractors are not 'human shields' for the soldiers in a military base, but explaining the distinction between them and civilians who support or acquiesce in insurgent activity is tricky. ${ }^{10}$ One might say that civilian cooks working for a counterinsurgent base have willingly agreed to put themselves in a situation in which they may be targeted - but, unless the insurgent hides his or her activities from others, the insurgent's family might be said to have done the same thing. And, in any event, it seems to be a mistake to treat the question of how one undertakes a fight against insurgents purely on the level of decisions made by individual people, using the model of mass battlefield combat. Integration with the broader population is just part of the moral and tactical terrain of insurgency and counterinsurgency, and the liability of any individual as result of his or her actions needs to be assessed against that background.

Care ethic's particularism is helpful for thinking through the relationship with civilians. Deciding who is 'really' a civilian or to what extent, in the abstract, a civilian is liable to counterinsurgent violence, misses the moral point. The counterinsurgent's moral task is not just to properly circumscribe the scope of her violence, but to understand why these civilians support these insurgents, and how she can rebuild the trust in this government. That requires respecting the interests and safety of civilians, but not by deciding who is in or out of the fight. Too much focus on discrimination may cause the counterinsurgent either to miss the moral contribution civilians make to the insurgency, or to downplay the moral significance of violence short of

10 Importantly, the distinction does not seem to nicely track Nagel's ([1972] 2008: 498) suggestion that we cannot target those who support soldiers in their "merely human" capacities, since this would apply to military cooks as well. Whether it would be acceptable to target a military installation where all the soldiers had left, leaving only cooks and other support staff is a question on which I will admit that I do not have a strong and settled intuition. 
killing - the proverbial 'kicking down doors.'

So, what virtues would a care ethics recommend that counterinsurgents develop, under these circumstances? Three virtues are especially appropriate to counterinsurgency: attentiveness, restraint, and creativity. ${ }^{11}$

Attentiveness is a disposition to be genuinely open to another's point of view on his or her own good. ${ }^{12}$ It is a crucial virtue for counterinsurgents - possibly even the 'master virtue,' since it helps define the contours of restraint and creativity by settling what counts as harm. While a focus on promoting the good of others is the core of a care ethics, mere benevolence is compatible with doing grievous harm when it is not coupled with sensitivity to the needs of the beneficiary. Since we tend to overestimate our ability to know what is good for others, we need to be sensitive to those needs as understood by the beneficiary. This is especially important in situations where the intended beneficiary's response to our actions may not be based purely on rational calculations of self-interest, but may include emotional responses that are best understood from his or her point of view - such as when a violent environment has caused fear or anger.

Counterinsurgents faced with resistance should ask themselves why this is so. They should also avoid assuming that resistance to a plan of action sincerely aimed at the population's own good is necessarily ignorant or unreasonable. Even where counterinsurgents decide they must persist in actions that civilians resist, they should understand the sources of that resistance and look for ways to at least make some restitution.

Ruddick focuses on a completely non-violent virtue of renunciation ([1989] 1995: 167-8), but the related virtue for counterinsurgents is restraint - a commitment to take suffering and risk on oneself whenever avoiding violence is possible. Restraint is necessary because counterinsurgents will be tempted to use violence where it is morally problematic or counterproductive. Faced with a hostile or recalcitrant population, in which it is difficult to distinguish civilians from threats, and given the superiority of military force that counterinsurgents usually possess, the 'easy' solution will often be to use force to eliminate perceived or anticipated threats. The attitude of restraint is important, in addition to learning rules of discrimination, since counterinsurgents will need to use judgment applying rules in uncertain situations (where a disposition to use violence when in doubt would be dangerous), and will need to deal with psychological effects such as fear and anger that tend to distort applications of rules. All at least

11 These virtues are found in some form in different treatments of care ethics, sometimes under different names. I have chosen labels I find agreeable.

12 Ruddick ([1989] 1995: 172-173) does not specifically call out a virtue of attentiveness, but emphasizes the mother's responsibility both to carefully consider the child's needs and help children learn to better articulate their needs (the latter a function that counterinsurgents might play as well, by creating forums for political discussion, etc.). See also Held, who calls this virtue "sensitivity" (2006: 53-54) and Slote, who treats the need to attend to the viewpoint of the person you are trying to help under the heading of "respect" (2007: 57-9). 
moderately disciplined militaries recognize the dangerous aspects of anger and fear, and so inculcate restraint (though not necessarily under that name), but it bears special mention in a counterinsurgency context (on disciplining anger, see Sherman 2004: Ch. 4).

Creativity is perhaps a less familiar virtue to the military. ${ }^{13}$ People resort to violence when they believe they have no other effective or appropriate options. Warfighters facing a recalcitrant or hostile population, even if committed to restraint, will best be able to avoid violence if they have cultivated a creative mindset that allows them to find other ways of meeting challenges.

Warfighters are defined by their ability to use violence, but they also have other means at their disposal, such as intimidation, interposition, propaganda, mediation/dialogue, and sometimes economic incentives or humanitarian assistance. Interestingly, creativity is closely tied to an oftcited non-moral virtue of counterinsurgency, accurate intelligence. The more that counterinsurgents know about the civilian population and the general situation, the better able they will be to find points of leverage that can be exploited without violence.

Serious attention to restraint and creativity may help blunt concerns about the use of force against civilians. If the issue of determining whether civilians involved with the insurgency (willingly or unwillingly) to this or that degree is distanced from the question 'who can we kill?' then we can honestly face questions about the moral particularities and dangers of coercing the civilian population without immediately assuming that any admission that there is a moral grey area here will license widespread violence against civilians. Tempting as it may be to hold the principle of discrimination absolutely sacrosanct, given the necessity of using some coercive measures against civilians to succeed in counterinsurgency, insisting that all uses of force against civilians are morally equivalent risks having the unintended and counterproductive effect of increasing counterinsurgent violence against civilians. If counterinsurgents are convinced that they are already 'over the line,' when they use what is perhaps reasonable coercion against civilians, there may be less moral incentive for refusing to go further.

\section{What About Combatants?}

So far, I have focused on the moral contours of the counterinsurgents' relationship with civilians. But counterinsurgents should also exhibit the virtues of restraint, creativity, and attentiveness with respect to combatants. Moral and practical separation of insurgents and civilians is an ideal for counterinsurgency, but it is not the reality.

While some insurgent groups make a practice of moving recruits out of the area in which they were recruited, in many cases insurgents remain part of their pre-insurgent lives, and connected to their communities. One insurgent described his comrades as 'peasants by day, rebels by night'

13 Again, Ruddick does not name this virtue, but I see it implied in her discussion of the ways in which parents and non-violent activists must find or create common interests, find ways of getting people to work together, and flexibly shift between non-violent conflict tactics and peacekeeping tactics ([1989] 1995: 172-5). 
(quoted in Kalyvas 2006: 415). Even if counterinsurgents make a clean separation between insurgents and others, not everyone is likely to do so - use of force against insurgents may well inspire anger and resentment among those who knew and cared about them in the community, even aside from any problems of 'collateral damage.'

Insurgents take up arms for a wide variety of reasons, few of which have anything to do with the overall project of the war. Combatants in a civil war are conscripts, they join to get revenge against the faction that attacked them, they join to make a living, they join because their family are rebels, they join for excitement, and sometimes they join because they share the goals of the insurgency (Kalyvas 2006: 95-7). In most of these cases, the violence used in the insurgency is not something morally separate from disputes and divisions in the broader community - it is just those disputes carried out through violent means, thanks to the availability of weapons, the lack of public order, and the presence of armed organizations through which disputes can be channeled.

This is not a plea to discard the civilian-combatant distinction. Those who use violence cross an important moral line. But killing all combatants is not the goal of counterinsurgency, either. It is telling that the tactics endorsed by mainstream counterinsurgency theory are a mix of those that will plausibly involve attacking insurgents with military force, and those that may well not.

For instance, the US Counterinsurgency field manual notes that combat operations are only a part of counterinsurgency operations. And then, even in the context of a discussion of combat and civil security operations, it lists multiple options for dealing with insurgent combatants, many of which do not necessarily involve violence. Under 'considerations for developing the combat operations/civil security operations LLO' [logical line of operations], 'eliminate' insurgent leaders comes last in a list of approaches, after 'win over, exhaust, divide, capture' (Headquarters, Department of the Army 2006: Table 5-2). The same table also lists a number of alternative actions appropriate for insurgents, that either do not involve the use of force, or may involve some use of force but are not aimed at killing insurgents:

Disrupt base areas and sanctuaries...

... stop insurgents from bringing materiel support across international and territorial borders...

Support efforts to disarm, demobilize, and reintegrate into society members of armed groups outside of government control, such as militias and paramilitary organizations. Also include insurgents who are captured, surrender, or accept amnesty.

While the field manual avers that '[m]easured combat operations are always required to address insurgents who cannot be co-opted into operating inside the rule of law' (Headquarters, Department of the Army 2006: para 5-38), the main goals it lists for combat operations are to secure the population against insurgent violence, isolate the population from the insurgency, combat crime, and secure the borders (Headquarters, Department of the Army 2006: Fig. 5-2). 
The practical point that it is better to co-opt or offer amnesty and reintegration to insurgents than to kill them impacts the moral relationship between counterinsurgents and insurgents. Insurgents are members of the very community that counterinsurgents are protecting. In fact, while 'isolation' of insurgents is a stated goal of counterinsurgency, the fact that reintegration is an option undercuts its importance - insurgents need only be isolated if it proves impossible to bring them back into the fold.

The emphasis on irreconcilable insurgents who must be killed that one sometimes hears (though, notably, not in the US manual) is based on a mistaken view of the nature of most insurgencies' combatant core. It would be futile to try to 'win over' insurgents, independently of winning the war, if one of two things were true: first, if insurgencies were tightly controlled hierarchical structures, capable of maintaining more or less perfect control and discipline in their ranks (hence preventing defections); or, otherwise, if most combatants were committed ideologues. The existence of multiple insurgent motivations undercuts the second possibility, and the first possibility is ruled out by the fact that most insurgencies are heavily reliant on the local population for support. A truly autonomous insurgency, that mimicked a state military in structure, would need to be relatively isolated from the community. One that is connected to the community, as most insurgencies are, will be subject to the need to adjust its activities in light of the compromises it makes with the community at large and will provide many opportunities for indiscipline if the insurgency's goals diverge from the interests its local members are pursuing. ${ }^{14}$

Because combatants are part of the community, a caring attitude towards insurgents is important, along with a caring attitude toward the rest of the population, including thinking about how to combine violence definitely needed against insurgents with care for them. Ending the insurgency will generally involve making cooperation with counterinsurgents, and ultimately disarmament and reintegration, attractive prospects for the bulk of insurgents. That requires both attention to the needs and desires of the insurgents, and the provision of credible security to them - including through the use of violence against other insurgents.

The parenting analogy that I discussed earlier is particularly strained with respect to the relationship between counterinsurgents and insurgents. It may even seem that the idea of building a relationship with certain kinds of insurgents - those involved in serious abuses and war crimes - is morally odious. But we can and do build relationships that are not based on positive feeling, and may include harsh moral opposition. If an analogy is needed, the relationship between counterinsurgents and insurgents is probably closest to the relationship

14 There may be some insurgencies that do not fit this model, and genuinely are practically separated from the community. Possible examples include seemingly purely predatory/destructive organizations such as the Lord's Resistance Army in Uganda and Renamo in Mozambique. It is not entirely clear that either group lacks/lacked all local support, even if much of that support was based on fear. But even if they did, many of the same considerations apply - both groups rely or relied heavily on conscription, and so providing effective guarantees of safety (however difficult that might be) to conscript members, along with credible promises of return to their communities, might be extremely effective ways of promoting defection. 
between estranged parents or family members. In such cases, some sort of relationship of trust must be built for the sake of people to whom we are mutually connected, even if it coexists with serious dislike, anger, or moral disagreement. And, at the same time, most such relationships hold open at least the possibility at of reconciliation, even if one is not really expected.

Let us consider how the virtues attentiveness, creativity, and restraint manifest with respect to combatants, and add another virtue to the list - a particular variety of courage.

First, the notion of attentiveness takes on an additional dimension. The US counterinsurgency manual mentions communicating a 'we know why you fight' attitude to the insurgents (Headquarters, Department of the Army 2006: Table 5-1). If taken to apply only to the main goals of the insurgency, this may miss the goals of individual insurgents. Providing insurgents with the security to cooperate with counterinsurgents may mean addressing much more local concerns - at the community level, or even at the individual level (e.g., ensuring that a legal system can provide punishment in lieu of personal revenge).

Second, restraint should be understood not only as restraint from the use of force but restraint in the use of force. Even when counterinsurgents must use violence (as to defend themselves from imminent attack, or drive insurgents away from an area), they have options regarding the scale and strategy of the violence they use. ${ }^{15}$

Creativity manifests in the same way here as before - as the virtue that allows counterinsurgents to find ways to fulfill their goals while restraining the obvious solution of force. Getting wrapped up with defeating insurgents by force is likely to be counterproductive. Rather, force should be used to protect the counterinsurgents themselves, and to protect the population. Given this focus, restrained strategies of violence become available - e.g., counterinsurgents may use 'protective engagement,' placing themselves around a vulnerable area (such as an internally displaced persons camp) to deter or repulse attacks.

Finally, caring counterinsurgency requires a specific sort of courage when combatants are involved. All warfighters recognize the value of courage, but counterinsurgency requires a special variety tightly connected to restraint. Counterinsurgents need to manifest the courage to refrain from the use of force sometimes even when they are threatened with force, a virtue more familiar perhaps to non-violent activists.

This is not to say that counterinsurgents should meekly lay down their weapons when they are being attacked. But being attacked from out of the blue is not the only or even the main situation

15 For instance, Pfaff (2000: 21) argues that military involved in missions aimed at keeping or enforcing peace should adhere to a police-like standard of "minimum necessary force," rather than what he takes to be the military standard of using "maximum allowable force" - even though the police standard involves assuming more risk. Pfaff's comments are based on the moral difference between the use of force in peace and war, but because many of the goals of counterinsurgency involve building toward a stable peacetime regime, they are apt here. 
in which counterinsurgents use force. When an insurgent or insurgent group is identified, it may well be better to take creative risks: for counterinsurgents to approach the leaders or individual members with incentives to cooperate, or to help bring humanitarian relief to an insurgent stronghold to win the broader population's loyalty, etc., even if this exposes them to attack.

\section{Conclusion: Caring Virtues and the Counterinsurgent}

Military forces would better be able to conduct counterinsurgency in a moral manner if they embraced the virtues of attentiveness, creativity, and restraint, as well as extending their understanding of courage to include holding back violence under threat as part of the core concept. This would bring the values inculcated in counterinsurgents into greater coherence with the tasks and attitudes expected of them.

I also believe that it is realistic to think that such virtues could be embraced by military forces, even though they may seem 'soft,' and at odds with a 'warrior ethos.'

But the warrior ethos already embodies a strong notion of interdependence, which resonates with care ethics. Warfighters are often encouraged to look on their comrades in arms as something like family, and norms of intra-group solidarity and support can be extremely strong. Individuals in war know that they are radically dependent on the performance of the others around them, and must not only trust them with their lives, but become trustworthy themselves. Building such relationships, especially when doing so requires overcoming intra-group conflicts of interests and values, all under the stress of life-and-death situations in which seeking personal safety at the expense of one's comrades may be tempting, requires all the virtues of caring.

Since my argument has focused on character virtues, the main practical implication of it would be for military training. Revising the traditional laws or moral rules of war is not the proper approach - a focus on care is orthogonal to the concerns that drive those rules, and can coexist with them. In counterinsurgency, the civilian/combatant distinction can become blurred by the presence of active civilian supporters, but I have argued that the appropriate response is to prepare counterinsurgents to responsibly navigate the use of coercion against civilians, not more finely delineate who they may and may not kill.

For the most part, inculcating the virtues of attentiveness, creativity, and restraint, and honing a caring sense of courage, is, I believe, compatible with mainstream military ethics training as it is practiced in most reasonably well-ordered militaries. It would extend this training, of course, but by building on familiar notions of service and responsibility, and extending the values involved in concern for one's comrades to the broader population in the area of operations.

There may be some conflicts, however, with the current way that (especially Western) warfighters are trained. Warfighters trained for conventional warfare, for instance, are trained for very fast response times to threats. Inculcating an attitude of restraint and creativity even toward 
enemy combatants will inevitably slow response times - a phenomenon that has been observed in individuals who have served in peace and stability operations, where immediate use of force may not be appropriate (even though these individuals have not been explicitly trained in the way I am recommending) (author interview with US military trainer, May 2009).

I must bite the bullet on this. Inculcating character traits is not the same as teaching rules, where an individual might mentally switch between two incompatible sets of rules, depending on the situation at hand. The whole point of building up virtues of creativity and restraint is that counterinsurgents will be trained to see the situation in a way that permits them to contemplate alternatives to force, before any conscious decisions have been made. The virtues of care are not rules, but habits of mind. Just as it may not be financially feasible to equip a military with the weapons and vehicles appropriate both to fighting a major conventional war and a counterinsurgency, it may well not be psychologically or morally possible to train warfighters who will act equally appropriately in two very different kinds of warfare.

The other concern arises when we lift my assumption about the justice of counterinsurgency. The justice of a counterinsurgency must be based in part on the goodness of the regime being protected for the individuals who will be governed by it. ${ }^{16}$ caring counterinsurgents, who are truly attentive to the needs and interests of those among whom they operate, cannot divorce themselves from thoughts of the war's overall justice. It would be morally incoherent to ask counterinsurgents to truly care about the good of people on the micro-level of their individual operations, but ignore their good on the macro-level of the war. Developing a care ethic is not a matter of learning rules of conduct; the ethics of care is essentially critical, in the sense of encouraging moral reflection and revision of one's moral understandings in light of others' viewpoints. A military that desires its counterinsurgents to conduct the war justly must provide some way for them to question the justice of the entire war effort, on pain of crippling and distorting the very caring moral attitude with which we should equip counterinsurgents.

16 There will, of course, be many other relevant considerations, especially for counterinsurgents operating in a country that is not their own. A full discussion of these is beyond the scope of this essay, but I would not want to give the impression that they were being ignored. 


\section{Reference List}

Coady, C.A.J. (2008) Morality and Political Violence (New York: Cambridge UP).

Cohn, C (1987) Sex and Death in the Rational World of Defense Intellectuals, Signs 12(4), pp. 687-718.

Engster, D (2007) The Heart of Justice: Care Ethics and Political Theory (New York: Oxford UP).

Headquarters, Department of the Army (2006) FM3-24: Counterinsurgency (Washington, DC: Headquarters, Dept. of the Army).

Held, V (2006) The Ethics of Care: Personal, Political, and Global (New York: Oxford UP).

Kalyvas, S (2006) The Logic of Violence in Civil War (New York: Cambridge UP).

Kant, I ([1785] 1993) Grounding for the Metaphysics of Morals, trans. James W. Ellington (Indianapolis, IN: Hackett).

McMahan, J (2009) Killing in War (New York: Oxford UP).

Nagel, T ([1972] 2008) War and Massacre, in Thom Brooks (Ed) The Global Justice Reader, pp. 488-501 (New York: Wiley-Blackwell).

Pfaff, T (2000) Peacekeeping and the Just War Tradition [report on-line] (Carlisle, PA: US Army War College Strategic Studies Institute) accessed 3 September 2009, available at http://www.strategicstudiesinstitute.army.mil/pubs/2000/justwar/justwar.pdf; Internet.

Ruddick, S (1989) Maternal Thinking: Towards a Politics of Peace (Boston: Beacon).

Sherman, N (2005) Stoic Warriors: The Ancient Philosophy Behind the Military Mind (New York: Oxford UP).

Slote, M (2007) The Ethics of Care and Empathy (New York: Routledge).

Solomon, D (2009) Questions for Ellen Johnson-Sirleaf: Madame President, New York Times Magazine 23 August 2009, p. MM16.

Stubbs, R (2008) From Search and Destroy to Hearts and Minds: The Evolution of British Strategy in Malaya 1948-60, in Daniel Marston and Carter Malkasian (Eds.) Counterinsurgency in Modern Warfare (New York: Osprey). 